\title{
Introduction of bacterial and viral pathogens from imported ornamental finfish in South Korea
}

\author{
Hee Jae $\mathrm{Choi}^{1 \dagger}$, Jun Wook Hur ${ }^{2 \dagger}$, Jae Bum Cho ${ }^{3}$, Kwan Ha Park ${ }^{4}$, Hye Jin Jung ${ }^{5^{*}}$ and Yue Jai Kang ${ }^{1^{*}}$ (D)
}

\begin{abstract}
Background: Live fish import may lead to the unintended introduction of pathogens. We examined the monthly distribution of microbial pathogens in ornamental finfish imported into South Korea over a 6-month period.

Results: Vibrio alginolyticus was detected in one lemon damsel in June and July; V. vulnificus was detected in one lemon damsel, one caerulean damsel, and one pearl-spot chromis and one ocellaris clownfish in July, April, and May, respectively; Photobacterium damselae was detected in one ocellaris clownfish and one caerulean damsel in June and July, respectively; $V$. anguillarum was detected in one pearl-spot chromis in February; $V$. harveyi was detected in one ocellaris clownfish and two mandarin fish in February and April, respectively; Yersinia ruckeri was detected in a pearlscale goldfish group in June and July and in two colored carp groups in July; and Lactococcus garvieae was detected in a lemon damsel group and a sutchi catfish group in July and May, respectively. European catfish virus, the only viral pathogen detected, was found in two sutchi catfish groups in May.

Conclusion: This study is the first to identify pathogenic species and the presence or absence of pathogens (nonquarantine diseases) in imported ornamental finfish. These results demonstrate that various pathogens with the potential to harm indigenous fish populations can accompany ornamental finfish imported into South Korea.
\end{abstract}

Keywords: Imported ornamental finfish, Non-quarantine diseases, Vibriosis, Bacterial pathogens, Viral pathogens

\section{Background}

The import value of live aquarium fish into South Korea has increased by more than twofold from $\$ 2.011$ million in 1997 to $\$ 4.724$ million in 2010 and continues to increase each year (Korea Agro-Fisheries \& Food Trade Corporation in South Korea). Most of the ornamental fish (90\%) imported into South Korea are freshwater species (about 1000 in total) that are cultured in aquariums. However, marine species (approximately 500) are caught in the wild. Most of the freshwater fish are imported from tropical Asian countries such as Malaysia, Indonesia, and China (Moravec et al. 1999), whereas marine fish are from Indonesia, the Philippines,

\footnotetext{
* Correspondence: poka96@sunmoon.ac.kr; kyj5088@hanmail.net

${ }^{\dagger}$ Hee Jae Choi and Jun Wook Hur contributed equally to this work. ${ }^{5}$ Department of Pharmaceutical Engineering \& Biotechnology, Sun Moon University, Asan-si, Republic of Korea

'Department of Aquatic Life Medical Sciences, Sun Moon University, Seonmun-ro 221 Tangjeong-myeon, Asan-si, Chungnam 336-708, Republic of Korea

Full list of author information is available at the end of the article
}

and Singapore. As a result, the large number of imported fish may have exacerbated the problem of exotic fish pathogens being brought into South Korea.

Import of a variety of live fish species can lead to the unintended introduction of pathogens. In Australia, for example, the government has stringent regulations for live imported ornamental species that include mandatory quarantine periods of $1-3$ weeks and health certification. Despite these measures, there have been many outbreaks of exotic viral, bacterial, fungal, protozoan, and metazoan infections among ornamental fish in Australian aquaculture farms. Aeromonas salmonicida is associated with ulcers in pearlscale goldfish (Carassius auratus), and Edwardsiella ictaluri with systemic disease in rosy barbs (Pethia conchonius) (Humphrey 1995). E. tarda was isolated from fighting fish (Betta splendens) imported from Singapore and quarantined in Australia in 1985 (Humphrey et al. 1986). Although E. tarda is a ubiquitous bacterium in freshwater environments, it was not known to cause mortality in aquafarm species and 
was found during a large survey of bacterial pathogens infecting salmonids in Australia between 1981 and 1985 (Humphrey et al. 1987). Furthermore, it was found to cause subdermal abscesses in wild eels (Anguilla reinhardtii) in Queensland in 1990 (Eaves et al. 1990) and mortality in farmed rainbow trout (Oncorhynchus mykiss) in New South Wales in 1993 (Reddacliff et al. 1996). Non-quarantined diseases are negligible. When however, a new or exotic disease is introduced, there is always the risk of serious pathogenic or transmissible diseases, resulting in enormous economic losses in commercial aquaculture or in wild aquatic systems.

The role of ornamental fish in the transmission of non-quarantine pathogens and the establishment of infection and disease has received little attention in South Korea. The Korean government has been investigating the influx of aquatic quarantine pathogens via imported living aquatic animals (National Fishery Products Quality Management Service in South Korea). However, these surveys had not focused on non-quarantine diseases associated with imported ornamental finfish until 2015.

We have addressed this in the current study by examining the presence of non-quarantine bacterial and viral pathogens in imported ornamental finfish, identification of the pathogens, and phylogenetic analysis of the diseases detected.

\section{Methods}

\section{Sampling of imported ornamental finfish}

We examined the presence of microbial pathogens in ornamental finfish imported into Korea. Ornamental finfish specimens varied in terms of the number of samples and their size and weight (Table 1). Imported fish were randomly sampled for 6 months from February through July 2016. Fish sampled included ocellaris clownfish (Amphiprion ocellaris), pearlscale goldfish (Carassius auratus), and Nile tilapia (Oreochromis niloticus) at ten fish per month. Sutchi catfish (Pangasius sutchi) was imported every month with 20 fish being sampled each month. Five fish each of lemon damsel (Pomacentrus moluccensis), caerulean damsel (Pomacentrus caeruleus), and whitetail dascyllus (Dascyllus aruanus) along with three pearl-spot chromis (Chromis notata) were sampled in February and March, followed by ten fish each per month being sampled April through July. Five colored carp (Cyprinus carpio haematopterus) were sampled in February, and ten were sampled each month from March through July. Mandarin fish (Synchiropus splendi$d u s$ ) were sampled over 4 months from February through May, at a frequency of five fish in February and March and ten in April and May.

\section{Selection of candidate bacterial and viral pathogens from imported ornamental finfish}

Bacterial and viral pathogens in ornamental finfish were selected based on those most likely to infect finfish according to information from the World Organization for Animal Health (OIE) and survey data from the National Fishery Products Quality Management Service (NFQS) in South Korea for species imported in 2012-2015. Specifically, we selected pathogens for which there are standard international methods for detection (Table 2). Bacterial pathogens included Lactococcus garvieae, Yersinia ruckeri (the cause of enteric redmouth disease $(E R M)$ ), and the etiological agents of vibriosis, such as Vibrio anguillarum, $V$. alginolyticus, $V$. harveyi, $V$. vulnificus, V. penaeicida, and Photobacterium damselae (formerly $V$. damsel). Viral pathogens included European catfish virus (ECV), infectious hematopoietic necrosis virus (IHNV), viral nervous necrosis (VNN), and infectious spleen and kidney necrosis virus-like (ISKNV-like). Olive flounder (Paralichthys olivaceus) artificially infected with Vibrio anguillarum or viral hemorrhagic septicemia virus (VHSV) was used as positive

Table 1 Number of imported ornamental finfish sampled per month. We examined a total of 581 fish representing 10 species

\begin{tabular}{|c|c|c|c|c|c|c|c|c|c|}
\hline \multirow[t]{2}{*}{ Water } & \multirow[t]{2}{*}{ Common name (scientific name) } & \multicolumn{6}{|c|}{ Total samples (fish) per month (2016) } & \multirow{2}{*}{$\begin{array}{l}\text { Average } \\
\text { length } \\
(\mathrm{cm})\end{array}$} & \multirow{2}{*}{$\begin{array}{l}\text { Average } \\
\text { weight } \\
\text { (g) }\end{array}$} \\
\hline & & February & March & April & May & June & July & & \\
\hline \multirow[t]{4}{*}{ Sea } & Colored carp (Cyprinus carpio haematopterus) & 5 & 10 & 10 & 10 & 10 & 10 & 5.3 & 1.21 \\
\hline & Pearlscale goldfish (Carassius auratus) & 10 & 10 & 10 & 10 & 10 & 10 & 5 & 5.53 \\
\hline & Sutchi catfish (Pangasius sutchi) & 20 & 20 & 20 & 20 & 20 & 20 & 8 & 2.41 \\
\hline & Nile tilapia (Oreochromis niloticus) & 10 & 10 & 10 & 10 & 10 & 10 & 5.0 & 2.57 \\
\hline \multirow[t]{6}{*}{ Fresh } & Pearl-spot chromis (Chromis notata) & 3 & 3 & 10 & 10 & 10 & 10 & 4.3 & 1.06 \\
\hline & Caerulean damsel (Pomacentrus caeruleus) & 5 & 5 & 10 & 10 & 10 & 10 & 5.5 & 2.24 \\
\hline & Lemon damsel (Pomacentrus moluccensis) & 5 & 5 & 10 & 10 & 10 & 10 & 4.3 & 1.44 \\
\hline & Mandarin fish (Synchiropus splendidus) & 5 & 5 & 10 & 10 & 0 & 0 & 7.3 & 5.91 \\
\hline & Whitetail dascyllus (Dascyllus aruanus) & 5 & 5 & 10 & 10 & 10 & 10 & 3.5 & 1.15 \\
\hline & Ocellaris clownfish (Amphiprion ocellaris) & 10 & 10 & 10 & 10 & 10 & 10 & 4.2 & 1.47 \\
\hline
\end{tabular}

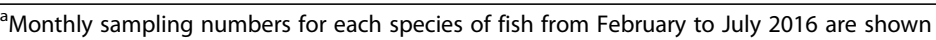


Table 2 PCR primers used for the detection of bacterial and viral pathogens

\begin{tabular}{|c|c|c|c|}
\hline Pathogen & Primer name & Sequence & Reference \\
\hline \multirow[t]{2}{*}{ L. garvieae } & pLG1 & 5'-CAT AAC AAT GAG AAT CGC-3' & \multirow[t]{2}{*}{ Baeck et al. 2006} \\
\hline & pLG2 & 5'-GCA CCC TCG CGG GTT G-3' & \\
\hline \multirow[t]{2}{*}{ Y. ruckeri } & YER8 & 5'-GCG AGG AGG AAG GGT TAA GTG-3' & \multirow[t]{2}{*}{ Gibello et al. 1999} \\
\hline & YER10 & 5'-GAA GGC ACC AAG GCA TCT CTG-3' & \\
\hline \multirow[t]{2}{*}{ V. anguillarum } & Van-ami8 F & 5'-ACA TCA TCC ATT TGT TAC-3' & \multirow[t]{2}{*}{ Gonzalez et al. 2003} \\
\hline & Van-ami417 R & 5'-CCT TAT CAC TAT CCA AAT TG-3' & \\
\hline \multirow[t]{2}{*}{ V. alginolyticus } & gyrB Fw & 5'-GAG AAC CCG ACA GAA GCG AAG-3' & \multirow[t]{2}{*}{ Zhou et al. 2007} \\
\hline & gyrB Re & 5'-CCT AGT GCG GTG ATC AGT GTT G-3' & \\
\hline \multirow[t]{2}{*}{ V. harveyi } & $\mathrm{VH}-4 \mathrm{~F}$ & 5'-GTG ATG AAG AAG CTT ATC GCG ATT-3' & \multirow[t]{2}{*}{ Kim et al. 2014} \\
\hline & $\mathrm{VH}-7 \mathrm{R}$ & 5'-CGC CTT CTT CAG TTA ACG CAG G-3' & \\
\hline \multirow[t]{2}{*}{ V. vulnificus } & vvhA Fw & 5'-TTC CAA CTT CAA ACC GAA CTA TGA-3' & \multirow[t]{2}{*}{ Panicker et al. 2004} \\
\hline & vvhA Re & 5'-ATT CCA GTC GAT GCG AAT ACG TTG-3' & \\
\hline \multirow[t]{2}{*}{ V. penaeicida } & FW & 5'-AA TAT TGC ACA ATG GGC GC-3' & \multirow[t]{2}{*}{ Saulnier et al. 2000} \\
\hline & $\operatorname{Re}$ & 5'-G CGC TाT ACG CCC AGT AAT TCC G-3' & \\
\hline \multirow[t]{2}{*}{ P. damselae } & PD-2F & 5'-CAA GAC ATC ATC GAT GTG ATG CGT-3' & \multirow[t]{2}{*}{ Kim et al. 2014} \\
\hline & PD-2R & 5'-GAA ACT TTA CCA TCT ACC ACT TTG-3' & \\
\hline \multirow[t]{2}{*}{ European catfish virus (ECV) } & FW & 5'-ATGCGCTCCTCCGGGTCAAAG-3' & \multirow[t]{2}{*}{ OIE 2011} \\
\hline & $\operatorname{Re}$ & 5'-CATCATGAACGGCTCGATGG-3' & \\
\hline \multirow[t]{2}{*}{ Infectious hematopoietic necrosis virus (IHNV) } & IHNV-GF & 5'-AGA GAT CCC TAC ACC AGA GAC-3' & \multirow[t]{2}{*}{ Emmenegger et al. 2000} \\
\hline & IHNV-GR & 5'-GGT GGT GTT GTT TCC GTG CAA-3' & \\
\hline \multirow[t]{2}{*}{ Viral nervous necrosis (VNN) } & VNN F & 5'-CGT GTC AGT CAT GTG TCG CT-3' & \multirow[t]{2}{*}{ Nishizawa et al. 1996} \\
\hline & VNN R & 5'-CGA GTC AAC ACG GGT GAA GA-3' & \\
\hline \multirow[t]{4}{*}{ Infectious spleen and kidney necrosis virus-like (ISKNV-like) } & P1 F & 5'-ATG TCT GCA ATC TCA GGT-3' & \multirow[t]{4}{*}{ Xu et al. 2008} \\
\hline & P2 R & 5'-TTA CAG GAT AGG GAA GCC TG-3' & \\
\hline & NP1 (NP nested) & 5'-GCG TाT GAT GCG ATG GAG AC-3' & \\
\hline & NP2 (NP nested) & 5'-ACG GCA GAG ACA CGG TAG GC-3' & \\
\hline
\end{tabular}

experimental controls for each polymerase chain reaction (PCR) assay used for disease identification. The positive control for the PCR method was used to eliminate uncertainty regarding the method of disease detection in PCR assay.

\section{Sampling of imported ornamental fish and identification of microbial pathogens}

To detect bacterial or viral infections in imported species, we analyzed quarantine records and procured regular samples from import companies listed in the NFQS. Samples were kept in their imported culture water, unexposed to the Korean environment. The finfish were anesthetized, their livers, spleens, and kidneys harvested using sterilized dissection tools, and the tissues evaluated for disease identification. As the first line of screening, we used thiosulphate-citrate-bile salts-sucrose (TCBS) agar plates as a selective medium for identifying Vibrio bacteria. To identify Vibrio spp., the yellow or green colonies on the TCBS medium were identified by
PCR assay. As a large number of yellow or green colonies of different types formed, these were classified according to those with the same morphology, and 5-10 different types of colonies were used for PCR diagnosis.

For detection of the other pathogens (L. garvieae, $Y$. ruckeri, ECV, IHNV, VNN, and ISKNV-like), the collected target organs of the finfish were pooled into two or four groups with five fish per group, and the genomic DNA extracted using a GeneAll Exgene Tissue SV kit (GeneAll Biotechnology, Seoul, Korea), or the genomic RNA derived from virus purified using a RNeasy Mini kit (Qiagen, Valencia, CA, USA). The RNA was reverse transcribed to generate cDNA using Power cDNA synthesis kit (INtRON, Korea). The isolated genomic DNA and cDNA were used as template in PCR assays to detect the genes of the pathogen.

\section{PCR assay}

Pathogen detection and analysis were performed using PCR methods previously described, as referenced in 
Table 2. Details on the primer sets used for the detection of each pathogen are shown in Table 2. PCR mixes contained $10 \mu \mathrm{l}$ of $2 \times$ ExPrime Taq $^{\mathrm{Tm}}$ Premix (GENET BIO, Korea), which included 1 unit of ExPrime Taq DNA Polymerase, Tris- $\mathrm{HCl}$ (pH 9.0), PCR enhancer, $(\mathrm{NH} 4)_{2} \mathrm{SO}_{4}, 4 \mathrm{mM} \mathrm{MgCl}$, enzyme stabilizer, sediment, loading dye, and $2.0 \mathrm{mM} \mathrm{dNTPs} \mathrm{mixture;} 0.5 \mu \mathrm{M}$ of each primer of the relative primer sets; $1 \mu \mathrm{l}$ of $10^{-1}$ diluted total DNA template; and distilled water to a final total volume of $20 \mu$ l. The thermal cycling profiles included an initial $95^{\circ} \mathrm{C}$ for $3 \mathrm{~min}$ (tissue-extracted DNA) or 10 min (colony-extracted DNA), then 30 sequential amplification cycles, followed by a final extension step of $72{ }^{\circ} \mathrm{C}$ for $7 \mathrm{~min}$. The amplification cycles were pathogenic-specific and consisted of denaturation at $95^{\circ}$ $\mathrm{C}$ for $30 \mathrm{~s}$, annealing at $50^{\circ} \mathrm{C}$ for $1 \mathrm{~min}$, and template extension at $72{ }^{\circ} \mathrm{C}$ for $30 \mathrm{~s}$ for L. garvieae, ESV, and IHNV; denaturation at $95^{\circ} \mathrm{C}$ for $30 \mathrm{~s}$, annealing at $58^{\circ} \mathrm{C}$ for 1 min, and template extension at $72{ }^{\circ} \mathrm{C}$ for $30 \mathrm{~s}$ for $V$. anguillarum, $V$. penaeicida, $V$. vulnificus, NNV, and ISKNV-like; or denaturation at $95^{\circ} \mathrm{C}$ for $30 \mathrm{~s}$, annealing at $60^{\circ} \mathrm{C}$ for $1 \mathrm{~min}$, and template extension at $72^{\circ} \mathrm{C}$ for $30 \mathrm{~s}$ for $Y$. ruckeri, $V$. harveyi, $V$. alginolyticus, and $P$. damselae. The PCR products were sequenced by Cosmo Genetech (Seoul, Korea) and confirmed using the basic local alignment search tool (BLAST) on the National Center for Biotechnology Information (NCBI) website (https://www.ncbi.nlm.nih.gov).

\section{Phylogenetic analysis}

For the bacterial pathogens, 16S rRNA gene sequences were obtained for L. garvieae, P. damselae, and Y. ruckeri. The gyrase B subunit (gyrB) gene sequence was obtained for $V$. alginolyticus. For the Vibrio spp., amiB sequences of $V$. anguillarum, which encode $N$-acetylmuramoyl-L-alanine amidase, RNA polymerase beta subunit $(r p o B)$ sequences of $V$. harveyi and $v v h B$ sequences of $V$. vulnificus, which encodes a chaperone, were obtained from analysis of the PCR products. For analysis of the viral pathogen ECV, gene sequences of the major capsid protein (MCP) were obtained. Each sequence detected was aligned using the NCBI GenBank database.

For phylogenetic analysis, the aligned sequences were evaluated using the MEGA 7 (Molecular Evolutionary Genetic Analysis 7) software program (Kumar et al. 2016). The alignments of the predicted protein or nucleotide sequences were revised by excluding regions with uncertain alignment at the ends of the sequences. The phylogenetic trees were constructed using the neighbor-joining method with bootstrap analysis (1000 replications), which showed that the pathogen genes detected in this study were placed into the same clade with respective species in GenBank.

\section{Results}

\section{Screening pathogens by TCBS agar culture and PCR} detection

We analyzed the monthly prevalence of bacterial and viral pathogens based on the total finfish samples (Table 3). Two pathogens were detected in February, $V$. anguillarum in a pearl-spot chromis and $V$. harveyi in an ocellaris clownfish. No pathogens were detected in the imported finfish tested in March. Among the fish species imported in April, there were two cases of $V$. harveyi detected in mandarin fish and one case of $V$. vulnificus detected in each of the pearl-spot chromis and caerulean damsel fish. In May, there was a positive finding for L. garvieae in a group of sutchi catfish, $V$. vulnificus in an ocellaris clownfish, and two cases of ECV detected in separate groups of sutchi catfish. In June, there was one case each of $Y$. ruckeri in a group of pearlscale goldfish, $P$. damselae in an ocellaris clownfish, and $V$. alginolyticus in a lemon damsel. In July, eight specimens were tested positive for genetic material from bacterial pathogens. These included three cases of vibriosis $(V$. alginolyticus in a lemon damsel, $V$. vulnificus in both a lemon damsel and a caerulean damsel, and $P$. damselae in a caerulean damsel); a case of Y. ruckeri in a pearlscale goldfish and two cases in separate groups of colored carp; and one case of L. garvieae in a lemon damsel.

\section{Phylogenetic analysis of screened pathogen gene sequences}

Phylogenetic trees based on the detected genes of the pathogens were generated using MEGA 7 software. Alignment with known sequences in the GenBank database showed that the genetic sequence detected in lemon damsel, which encoded for only 385-aa, had a high similarity (99\%) with the 16S rRNA genes of L. garvieae from Oncorhynchus mykiss (KM604702.1) in India and Oreochromis niloticus (KM209202.1) in Indonesia. The 388-aa fragment detected in ocellaris clownfish showed 99\% similarity with GenBank sequences for the 16S rRNA gene of $P$. damselae from Lates calcarifer in India (MF164181.1) and 96\% similarity with Oplegnathus fasciatus of China (KF956381.1) (Fig. 1a). The genetic sequence derived from the pathogen isolated from the colored carp encoded for a 496-aa fragment and shared 99\% similarity with the 16S rRNA gene of Y. ruckeri from Salmo salar of Norway (CP023184.1) and grass carp of China (KF003196.1) (Fig. 1b).

In the Vibrio spp., the 349-aa gyrB sequence isolated from the lemon damsel showed relatedness to $V$. alginolyticus from Trachurus trachurus in Japan (CAR48209.1) with a $97 \%$ sequence similarity (Fig. 1c). The 551-aa fragment of the $V$. anguillarum $a m i B$ that was detected in pearl-spot chromis had $99 \%$ similarity to the $a m i B$ of 
Table 3 Pathogens detected by polymerase chain reaction in imported finfish sampled from February to July 2016 (5 fish/group)

\begin{tabular}{|c|c|c|c|c|c|c|c|}
\hline \multirow[t]{2}{*}{ Fish sample } & \multirow[t]{2}{*}{ Pathogen } & \multicolumn{6}{|c|}{ Number of pathogen-positive fish (or group)/total fish sampled by month } \\
\hline & & February & March & April & May & June & July \\
\hline \multirow[t]{3}{*}{ Ocellaris clownfish } & V. harveyi & $1 \mathrm{fish} / 10$ & $0 / 10$ & $0 / 10$ & $0 / 10$ & $0 / 10$ & $0 / 10$ \\
\hline & P. damselae & $0 / 10$ & $0 / 10$ & $0 / 10$ & $0 / 10$ & $1 \mathrm{fish} / 10$ & $0 / 10$ \\
\hline & V. vulnificus & $0 / 10$ & $0 / 10$ & $0 / 10$ & $1 \mathrm{fish} / 10$ & $0 / 10$ & 0/10 \\
\hline Pearlscale goldfish & Y. ruckeri & $0 / 10$ & $0 / 10$ & $0 / 10$ & 0/10 & 1 group/10 & 1 group/10 \\
\hline \multirow[t]{2}{*}{ Sutchi catfish } & L. garvieae & $0 / 20$ & $0 / 20$ & $0 / 20$ & 1 group/20 & $0 / 20$ & $0 / 20$ \\
\hline & ECV & $0 / 20$ & $0 / 20$ & $0 / 20$ & 2 groups/20 & $0 / 20$ & $0 / 20$ \\
\hline \multirow[t]{3}{*}{ Lemon damsel } & L. garvieae & $0 / 5$ & $0 / 5$ & $0 / 10$ & 0/10 & 0/10 & 1 group/10 \\
\hline & V. alginolyticus & $0 / 5$ & $0 / 5$ & $0 / 10$ & 0/10 & $1 \mathrm{fish} / 10$ & 1 fish/10 \\
\hline & V. vulnificus & $0 / 5$ & $0 / 5$ & $0 / 10$ & $0 / 10$ & $0 / 10$ & 1 fish/10 \\
\hline \multirow[t]{2}{*}{ Pearl-spot chromis } & V. anguillarum & 1 fish/3 & $0 / 3$ & $0 / 10$ & $0 / 10$ & $0 / 10$ & $0 / 10$ \\
\hline & V. vulnificus & $0 / 3$ & $0 / 3$ & 1 fish/10 & 0/10 & $0 / 10$ & $0 / 10$ \\
\hline \multirow[t]{2}{*}{ Caerulean damsel } & V. vulnificus & $0 / 5$ & $0 / 5$ & 1 fish/10 & $0 / 10$ & $0 / 10$ & 1 fish/10 \\
\hline & P. damselae & $0 / 5$ & $0 / 5$ & $0 / 10$ & $0 / 10$ & $0 / 10$ & 1 fish/10 \\
\hline Colored carp & Y. ruckeri & $0 / 5$ & $0 / 10$ & $0 / 10$ & $0 / 10$ & $0 / 10$ & 2 groups/10 \\
\hline Mandarin fish & V. harveyi & $0 / 5$ & $0 / 5$ & $2 \mathrm{fish} / 10$ & 0/10 & - & - \\
\hline Whitetail dascyllus & - & $0 / 5$ & $0 / 5$ & $0 / 10$ & $0 / 10$ & 0/10 & 0/10 \\
\hline Nile tilapia & - & $0 / 10$ & $0 / 10$ & $0 / 10$ & $0 / 10$ & $0 / 10$ & 0/10 \\
\hline
\end{tabular}

V. anguillarum isolated from Lateolabrax japonicus of China (CP016095.1) (Fig. 1d). The 481-aa region of rpoB detected in mandarin fish demonstrated $99 \%$ identity to $V$. harveyi rpoB from Trachinotus ovatus of China (CP018680.2) (Fig. 1e). The 579-aa segment of V. vulnificus vvhB detected in caerulean damsel was 94\% similar to $V$. vulnificus vvhB from Mya arenaria (CP016322.1), Mactra veneriformis (CP015513.1) of South Korea, Oreochromis of Taiwan (CP009262.1), and eastern oyster of the USA (KF255370.1) (Fig. 1f).

In addition to the bacterial sequences detected, the viral sequences also aligned with known sequences in the GenBank database. The 395-aa fragment of the ECV MCP gene detected from sutchi catfish demonstrated 99\% sequence similarity with the ECV gene of Silurus glanis of Spain (YP 006347612.1) (Fig. 1g).

\section{Discussion}

The occurrence of bacterial or viral diseases in aquaculture is a major problem that can lead to enormous economic losses worldwide. Vibrio species are widely distributed in marine environments and estuaries and are some of the most abundant pathogens in aquafarms (Austin and Austin 1993a; Bergh et al. 2001; Hjeltnes and Roberts 1993; Lightner 1993). V. anguillarum, $V$. alginolyticus, $V$. harveyi, and $V$. vulnificus are among the main pathogens causing vibriosis in several finfish species (Austin and Zhang 2006; Balebona et al. 1998b; Romalde 2002), including in South Korea.
We detected the $V$. alginolyticus gyrB gene in lemon damsel during a 2-month period (detection rates of $10 \%$ in both June and July). The gyrB gene detected in caerulean damsel had $97 \%$ similarity with the $V$. alginolyticus isolate from Trachurus in Japan according to sequence alignment and analysis, with a close association being demonstrated in the phylogenetic tree. $V$. alginolyticus is responsible for epizootic outbreaks and mortality in farmed gilt-head sea bream (Sparus aurata L.) and puffer fish (Fugu vermicularis vermicularis) (Balebona et al. 1998b; Colorni et al. 1981; Noguchi et al. 1987) and has caused massive losses for the aquaculture industry in China (Xie et al. 2005). In sea bream, symptoms of infection include septicemia, hemorrhage, and fluid accumulation in the peritoneal cavity (Balebona et al. 1998a; Colorni et al. 1981). Ours is the first report of $V$. alginolyticus infection in lemon damsel.

$V$. vulnificus was detected in lemon damsel in July, caerulean damsel in April and July, pearl-spot chromis in April, and ocellaris clownfish in May, at a $10 \%$ detection rate in each case. Phylogenetic analysis revealed that the $v v h B$ detected in caerulean damsel shared $94 \%$ similarity with the $V$. vulnificus isolates from Mya arenaria and Mactra veneriformis of South Korea. This pathogen has been shown to cause infectious diseases in Japanese and European eels in Spain, Sweden, and Norway (Biosca et al. 1991, 1997; Muroga et al. 1976). V. vulnificus has been detected in marine fish collected along the west coast of India at an incidence of $16.6 \%$ (Thampuran and Surendran 1998) and has also been detected in 


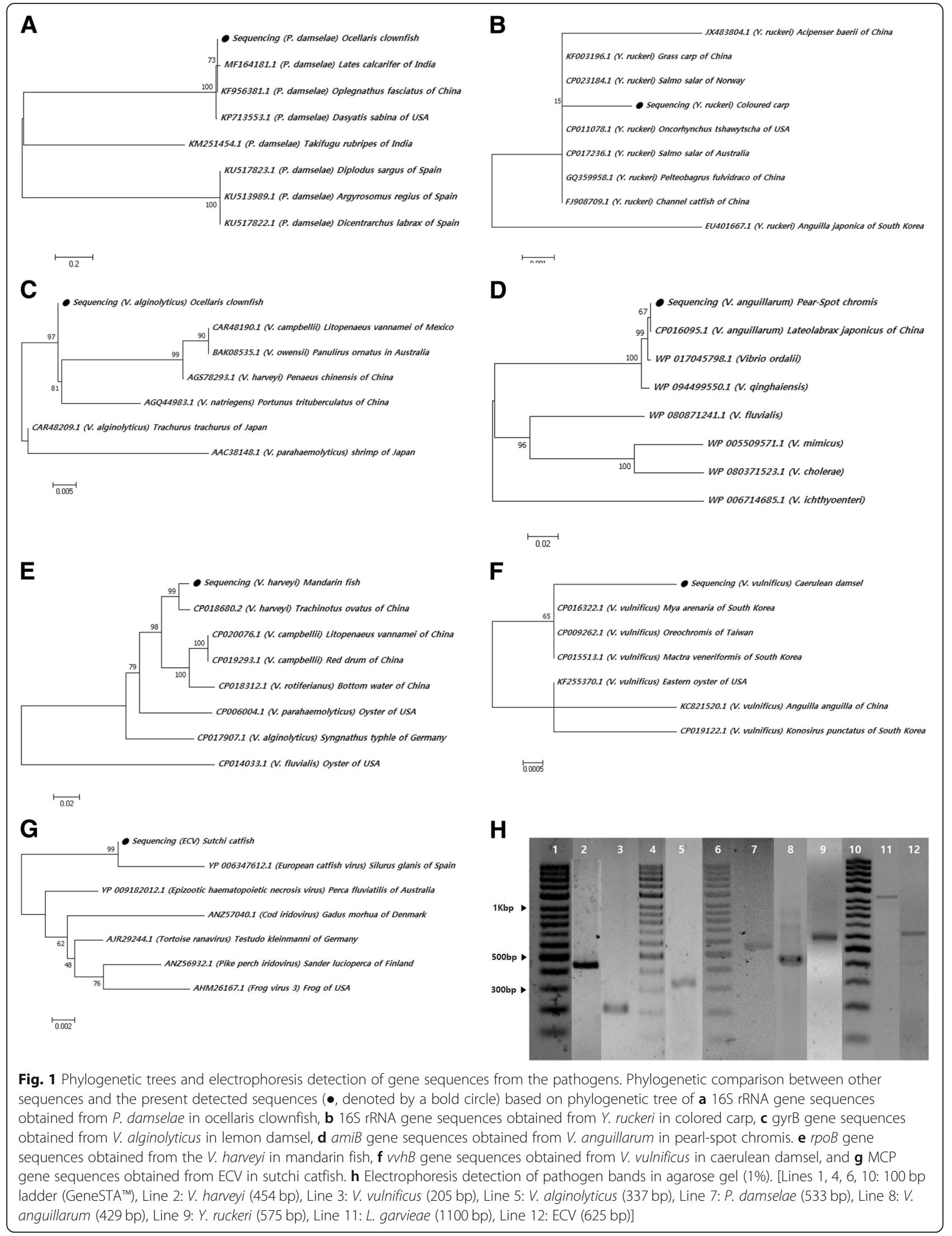


other countries such as Spain, the Netherlands, and Japan.

$V$. anguillarum was detected in approximately $1 / 3$ of pearl-spot chromis imported in February. The $a m i B$ of $V$. anguillarum that was detected from pearl-spot chromis had $99 \%$ similarity with the $a m i B$ of $V$. anguillarum derived from Lateolabrax japonicus of China. V. anguillarum was first reported in European eels (Bergman 1909) and is widely found in both cultured and wild fish, including Salmo salar L. (salmon), rainbow trout (Oncorhynchus mykiss), bream, eel, mullet, catfish, and tilapia (Oreochromis spp.) in salt or brackish water. Infections cause fatal hemorrhagic septicemic disease (Aguirre-Guzman et al. 2004; Frans et al. 2011; Paillard et al. 2004; Toranzo et al. 2005).

The $V$. harveyi rpoB sequence was detected in ocellaris clownfish (10\% infection rate in February) and mandarin fish $(20 \%$ infection rate in April). The rpoB gene sequence detected in the mandarin fish demonstrated 99\% identity with the gene from Trachinotus ovatus of China. This pathogen is known to affect crevalle jack (Caranx hippos), summer flounder (Paralichthys dentatus), sandbar shark (Carcharhinus plumbeus), and lemon shark (Negaprion brevirostris) (Austin and Zhang 2006; Kraxberger-Beatty et al. 1990; Bertone et al. 1996; Colwell and Grimes 1984; Grimes et al. 1984; Lee et al. 2002; Soffientino et al. 1999).

P. damselae was detected in ocellaris clownfish $(10 \%$ detection rate in June) and in caerulean damsel (10\% detection rate in July). Analysis of $P$. damselae using the $16 \mathrm{~S}$ rRNA gene detected in ocellaris clownfish revealed that it had $96 \%$ similarity to the $P$. damselae derived from Oplegnathus fasciatus of China and resulted in the relatedness demonstrated by the phylogenetic tree. This pathogen has previously been shown to affect cultures of red-banded sea bream, common sea bream, white seabream, and marine rainbow trout in Denmark (Labella et al. 2011; Pedersen et al. 2009). The mortality rates range between $5 \%$ and $94 \%$ depending on the season, and the species and age of the fish (Labella et al. 2011).

L. garvieae was detected in lemon damsel (50\% infection rate in July) and sutchi catfish (25\% infection rate in May). Sequencing analysis of the 16S rRNA gene detected in lemon damsel had high similarity (99\%) with the L. garvieae 16S rRNA gene isolated from Oncorhynchus mykiss in India and Oreochromis niloticus in Indonesia. This pathogen was first discovered in rainbow trout raised on a Japanese fish farm in the 1950s (Hoshina et al. 1958) but has since been isolated as a disease-causing agent in rainbow trout, yellowtail, tilapia, Japanese eel (Anguilla japonica), olive flounder (Paralichthys olivaceus), gray mullet catfish, wild wrasse (Coris aygula), black rockfish (Sebastes schlegeli), amberjack (Seriola dumerili), and kingfish (Seriola lalandi) (Chen et al. 2001; Colorni et al. 2003; Fadaeifard et al. 2012; Kang et al. 2004; Kawanishi et al. 2005; Kusuda et al. 1991; Lee et al. 2001; Prieta 1993; Ravelo et al. 2003). Various countries with aquafarms have reported L. garvieae infections, including Israel, Italy, Taiwan, Spain, Japan, Australia, Turkey, and the UK (Baya et al. 1990; Eldar et al. 1994, 1995, 1996; Kitao 1993; Kusuda et al. 1976; Nieto et al. 1995; Rasheed and Plumb 1984), as well as South Korea (Kang et al. 2004).

Y. ruckeri was detected in pearlscale goldfish (one of two groups in June and July each) and colored carp (both groups in July). The Y. ruckeri $16 \mathrm{~S}$ rRNA gene derived from colored carp showed $99 \%$ similarity with the Y. ruckeri 16S rRNA gene isolated from Salmo salar of Norway and grass carp of China. The disease ERM, which is caused by $Y$. ruckeri, can lead to mortality in farmed salmonids (Austin and Austin 1993b). There have been no reports to date of ERM in pearlscale goldfish or colored carp; in addition, it has only been associated with farmed eel in South Korea (Joh et al. 2010, 2013).

Finally, ECV was the only viral pathogen detected in the current study but was found at a rate of $10 \%$ in sutchi catfish imported in May. The ECV MCP gene detected in sutchi catfish showed $99 \%$ sequence similarity with that isolated from Silurus glanis of Spain. In Germany, ECV caused high morbidity and mortality in sheatfish and catfish hosts in a 1989 outbreak, causing $100 \%$ mortality in infected fish (Ahne et al. 1989).

In this study, Vibrio species, L. garvieae and P. damselae, were already known to exist in South Korea, but ECV and Y. ruckeri have not been reported in South Korea yet. Therefore, Y. ruckeri and ECV are exotic infectious diseases, and it is necessary to continuously monitor and analyze the effects of the pathogenicity of these diseases.

We were unable to identify any individuals in the imported samples with unusual symptoms of disease infection. The culture water imported with the samples was cloudy only for the lemon damsel and ocellaris clownfish. However, we did not detect pathogens in culture water. We did not observe any symptoms of latent stage diseases in the ornamental finfish. We also screened for genes of $V$. penaeicida, IHN, VNN, and ISKNV-like as pathogens in imported finfish, but none were detected during the sampling period of the study. Furthermore, we did not detect genes of the selected pathogens in whitetail dascyllus or Nile tilapia during the test period.

\section{Conclusions}

The frequency of detecting bacterial and viral pathogens among the finfish imported into South Korea from February through July 2016 gradually increased over time. 
This may have been associated with an increase in water temperature. Domestic interest in imported aquatic species is increasing; exotic finfish are bred as a hobby, as well as for consumption. However, this may lead to an increase in imported pathogens in South Korea. In Australia, a wide range of viruses, bacteria, and parasites was identified in ornamental fish during quarantine in the period from 1999 to 2004 (Chong and Whittington 2005), and these pathogens had negative effects in aquatic animals. It is therefore essential to exercise greater caution during importation and to engage in more careful monitoring of infectious diseases in South Korea to protect indigenous aquatic species. This study was the first to identify the species and origin of the detected pathogens and the presence or absence of pathogens (non-quarantine diseases) in imported ornamental finfish. Future studies will investigate pathogenicity in finfish using stock cultures of the pathogens responsible for the diseases that were detected.

\section{Abbreviations}

BLAST: Basic local alignment search tool; ECV: European catfish virus; IHNV: Infectious hematopoietic necrosis virus; MCP: Major capsid protein; NCBI: National Center for Biotechnology Information; NFQS: National Fishery Products Quality Management Service; PCR: Polymerase chain reaction; TCBS: Thiosulphate-citrate-bile salts-sucrose; VHSV: Viral hemorrhagic septicemia virus; VNN: Viral nervous necrosis

\section{Acknowledgements}

Not applicable.

\section{Funding}

Not applicable.

\section{Availability of data and materials}

All datasets generated during and/or analyzed during the current study are available from the corresponding author on reasonable request.

\section{Authors' contributions}

All authors designed this study and they read and approved the final manuscript.

\section{Ethics approval and consent to participate}

Not applicable.

\section{Competing interests}

The authors declare that they have no competing interests.

\section{Publisher's Note}

Springer Nature remains neutral with regard to jurisdictional claims in published maps and institutional affiliations.

\footnotetext{
Author details

'Department of Aquatic Life Medical Sciences, Sun Moon University, Seonmun-ro 221 Tangjeong-myeon, Asan-si, Chungnam 336-708, Republic of Korea. ${ }^{2}$ Bio-Monitoring Center, Sejong-si, Republic of Korea. ${ }^{3}$ National Fishery Products Quality Management Service, Busan-si, Republic of Korea. ${ }^{4}$ Department of Aquatic Life Medicine, Kunsan National University, Gunsan-si, Republic of Korea. ${ }^{5}$ Department of Pharmaceutical Engineering \& Biotechnology, Sun Moon University, Asan-si, Republic of Korea.
}

Received: 25 October 2018 Accepted: 30 January 2019

Published online: 19 February 2019

\section{References}

Aguirre-Guzman G, Ruiz HM, Ascencio F. A review of extracellular virulence product of Vibrio species important in diseases of cultivated shrimp. Aquac Res. 2004:35:1395-404.

Ahne W, Schlotfeldt HJ, Thomsen I. Fish viruses: isolation of an icosahedral cytoplasmic deoxyribovirus from sheatfish (Silurus glanis). Zentralbl Veterinarmed B. 1989;36:333-6.

Austin B, Austin DA. Vibriosis. In: Austin B, Austin DA, editors. Bacterial fish pathogens and disease in farmed wild fish. England: Springer; 1993a. p. 263-87.

Austin B, Austin DA. Bacterial fish pathogens: diseases in farmed and wild fish (2nd ed.) Chichester, UK: Springer; 1993b.

Austin B, Zhang XH. Vibrio harveyi: a significant pathogen of marine vertebrates and invertebrates. Lett Appl Microbiol. 2006;43:119-24.

Baeck GW, Kim JH, Gomez DK \& Park SC (2006) Isolation and characterization of Streptococcus sp. from diseased flounder (Paralichthys olivaceus) in Jeju Island. Journal of Veterinary Science 7, 53-58.

Balebona MC, Andreu MJ, Bordas MA, Zorrilla I, Moriñigo MA, Borrego JJ. Pathogenicity of Vibrio alginolyticus for cultured gilt-head sea bream (Sparus aurata L.). Appl Environ Microbiol. 1998a;64:4269-75.

Balebona MC, Zorrilla I, Moriñigo MA, Borrego JJ. Survey of bacterial pathologies affecting farmed gilt-head sea bream (Sparus aurata L.) in southwestern Spain from 1990 to 1996. Aquaculture. 1998b;166:19-35.

Baya AM, Lupiani B, Hetrick FM, Robertson BS, Lukacovic R, May E, et al. Association of Streptococcus sp. with mortalities in the Chesapeake Bay and its tributaries. J Fish Dis. 1990;13:251-3.

Bergh O, Nilsen F, Samuelsen OB. Diseases, prophylaxis and treatment of the Atlantic halibut Hippoglossus: a review. Dis Aquat Org. 2001;48:57-74.

Bergman AM. Die roten Beulenkrankheit ds Aales. Berichte aus der Königlich Bayerischen Biologischen Versuchsstation. 1909;2:10-54.

Bertone S, Gili C, Moizo A, Calegari L. Vibrio carchariae associated with a chronic skin ulcer on a shark, Carcharhinus plumbeus (Nardo). J Fish Dis. 1996;19:42934.

Biosca EG, Amaro C, Esteve C, Alcaide E, Garay E. First record of Vibrio vulnificus biotype 2 from diseased European eel, Anguilla L. J Fish Dis. 1991;14:103-9.

Biosca EG, Amaro C, Larsen JL, Pedersen K. Phenotypic and genotypic characterization of Vibrio vulnificus: proposal for the substitution of the subspecific taxon biotype for serovar. Appl Environ Microbiol. 1997;63:14606.

Chen SC, Lin YD, Liaw LL, Wang PC. Lactococcus garvieae infection in the giant freshwater prawn Macrobrachium rosenbergii confirmed by polymerase chain reaction and 165 rDNA sequencing. Dis Aquat Org. 2001;45:45-52.

Chong $\mathrm{R}$, Whittington RJ. A review of Australian ornamental fish import risk management for the period 1999-2004. A report to the National Aquatic Animal Health Technical Working Group. University of Sydney and Department of Primary Industries and Fisheries Queensland, Camden, Yeerongpilly. 2005.

Colorni A, Paperna I, Gordin H. Bacterial infections in gilt-head sea bream Sparus aurata cultured at Elat. Aquaculture. 1981;23:257-67.

Colorni A, Ravelo C, Romalde JL, Toranzo AE, Diamant A. Lactococcus garvieae in wild Red Sea wrasse Coris aygula (Labridae). Dis Aquat Org. 2003;56:275-8.

Colwell RR, Grimes DJ. Vibrio diseases of marine fish populations. Helgolander Meeresun. 1984;37:265-87.

Eaves L, Ketterer P, Anderson I, Beumer J. The isolation and identification of Edwardsiella tarda from a diseased native Australian eel (Anguilla reinhardtii). Aust Vet J. 1990;67:336-7.

Eldar A, Bejerano Y, Bercovier H. Streptococcus shiloi and Streptococcus difficile: two new streptococcal species causing a meningoencephalitis in fish. Curr Microbiol. 1994;28:139-43.

Eldar A, Frelier PF, Assenta L, Varner PW, Lawhon S, Bercovier H. Streptococcus shiloi, the name for an agent causing septicemic infection in fish, is a junio synonym of Streptococcus iniae. Int J Syst Evol Microbiol. 1995:45:840-2.

Eldar A, Ghittino C, Asanta L, Bozzetta E, Goria M, Prearo M, et al. Enterococcus seriolicida is a junior synonym of Lactococcus garviae, a causative agent of septicemia and meningoencephalitis in fish. Curr Microbiol. 1996:32:85-8.

Emmenegger EJ, Meyers TR, Burton TO, Kurath G. Genetic diversity and epidemiology of infectious hematopoietic necrosis virus in Alaska. Dis Aquat Org. 2000;40:163-76. 
Fadaeifard F, Momtaz H, Rahimi E, Mirzakhani A. Detection of Streptococcus iniae and Lactococcus garvieae by multiplex polymerase chain reaction (PCR) in some rainbow trout farms of Iran. African J Biotechnol. 2012;11:260-3.

Frans I, Michiels CW, Bossier P, Willems KA, Lievens B, Rediers H. Vibrio anguillarum as a fish pathogen: virulence factors, diagnosis and prevention. J Fish Dis. 2011;34:643-61.

Gibello A, Blanco MM, Moreno MA, Cutuli MT, Domenech A, Dominguez L, et al. Development of a PCR assay for detection of Yersinia ruckeri in tissues of inoculated and naturally infected trout. Appl Environ Microbiol. 1999;65: 346-50.

Gonzalez SF, Osorio CR, Santos Y. Development of a PCR-based method for the detection of Listonella anguillarum in fish tissues and blood samples. Dis Aquat Org. 2003;55:109-15.

Grimes DJ, Colwell RR, Stemmler J, Hada H, Maneval D, Hetrick FM, et al. Vibrio species as agents of elasmobranch disease. Helgolander Meeresun. 1984;37: 309-15.

Hjeltnes B, Roberts RJ. Vibriosis. In: Roberts RJ, Bromag NR, Inglis V, editors. Bacterial diseases of fish. Oxford: Blackwell Scientific; 1993. p. 109-21.

Hoshina T, Sano T, Morimoto Y. A Streptococcus pathogenic to fish. J Tokyo Univ Fish. 1958:44:57-8.

Humphrey JD. Australian quarantine policies and practices for aquatic animals and their products: a review for the scientific working party on aquatic animal quarantine. Part I: Review and Annexes PART II Appendices. Canberra: Bureau of Resource Sciences; 1995. p. 264.

Humphrey JD, Lancaster C, Gudkovs N, McDonald W. Exotic bacterial pathogens Edwardsiella tarda and Edwardsiella ictaluri from imported ornamental fish Betta splendens and Puntius conchonius, respectively: isolation and quarantine significance. Aust Vet J. 1986;63:369-71.

Humphrey JD, Lancaster CE, Gudkovs N, Copland JW. The disease status of Australian salmonids: bacteria and bacterial diseases. J Fish Dis. 1987;10 403-10.

Joh SJ, Ahn EH, Lee HJ, Shin GW, Kwon JH, Park CG. Bacterial pathogens and flora isolated from farm-cultured eels (Anguilla japonica) and their environmental waters in Korean eel farms. Vet Microbiol. 2013;163:190-5.

Joh SJ, Kweon CH, Kim MJ, Kang MS, Jang H, Kwon JH. Characterization of Yersinia ruckeri isolated from the farm-cultured eel Anguilla japonica in Korea. Korean J Vet Res. 2010;50:29-35.

Kang SH, Shin GW, Shin YS, Palaksha KJ, Kim YR, Yang HH, et al. Experimental evaluation of pathogenicity of Lactococcus garvieae in black rockfish (Sebastes schlegeli). J Vet Sci. 2004:5:387-90.

Kawanishi A, Kojima A, Ishihara K, Esaki H, Kijima M, Takahashi T, et al. Drug resistance and pulsed-field gel electrophoresis patterns of Lactococcus garvieae isolates from cultured Seriola (yellowtail, amberjack and kingfish) in Japan. Lett Appl Microbiol. 2005;40:322-8.

Kim MS, Cho JY, Choi HS. Identification of Vibrio harveyi, Vibrio ichthyoenteri, and Photobacterium damselae isolated from olive flounder Paralichthys olivaceus in Korea by multiplex PCR developed using the rpoB gene. Fish Sci. 2014;80: 333-9.

Kitao T. Streptococcal infection. In: Roberts RJ, Bromag NR, Inglis V, editors. Bacterial diseases of fish. Oxford: Blackwell Scientific; 1993. p. 196-210.

Kraxberger-Beatty T, McGarey DJ, Grier HJ, Lim DV. Vibrio harveyi, an opportunistic pathogen of common snook, Centropomus undecimalis (Block), held in captivity. J Fish Dis. 1990;13:557-60.

Kumar S, Stecher G, Tamura K. MEGA7: molecular evolutionary genetics analysis version 7.0 for bigger datasets. Mol Biol Evol. 2016;33:1870-4.

Kusuda K, Kawai K, Salati F, Banner CR, Fryer JL. Enterococcus seriolicida sp. nov, a fish pathogen. Int J Syst Bacteriol. 1991;41:406-9.

Kusuda R, Kawai K, Toyoshima T, Komatsu I. A new pathogenic bacterium belonging to genus Streptococcus isolated from an epizootic of cultured yellowtail. Bull Jpn Soc Sci Fish. 1976;42:1345-52.

Labella A, Berbel C, Castro D, Borrego JJ, Manchado M. Photobacterium damselae subsp. damselae, an emerging pathogen affecting new cultured marine fish species in southern Spain. In: Aral F, Doğu Z, editors. Recent advances in fish farms, vol. 2. Rijeka: InTech; 2011. p. 10-54.

Lee DC, Lee Jl, Park Cl, Park SI. The study on the causal agent of streptococcosis (Lactococcus garvieae), isolated from cultured marine fish. J Fish Pathol. 2001; $14: 71-80$.

Lee KK, Liu PC, Chuang WH. Pathogenesis of gastroenteritis caused by Vibrio carchariae in cultured marine fish. Mar Biotechnol. 2002;4:267-77.
Lightner DV. Diseases of cultured penaeid shrimp. In: McVey JP, editor. CRC handbook of mariculture, 2nd edition, volume 1. Boca Raton: CRC Press; 1993. p. 393-486

Moravec F, Wolter J, Korting W. Some nematodes and acanthocephalans from exotic ornamental freshwater fishes imported into Germany. Folia Parasitol. 1999:46:296-310.

Muroga K, Jo Y, Nishibuchi M. Pathogenic vibrio isolated from cultured eels I. Fish Pathol. 1976;11:141-5.

Nieto JM, Devesa S, Quiroga I, Toranzo AE. Pathology of Enterococcus sp. infection in farmed turbot, Scophthalmus maximus L. J Fish Dis. 1995;18: 21-30.

Nishizawa T, Muroga K, Arimoto M. Failure of the polymerase chain reaction (PCR) method to detect striped jack nervous necrosis virus (SJNNV) in striped jack Pseudocaranx dentex selected as spawners. J Aquat Anim Health. 1996;8: 332-4.

Noguchi T, Hwang DF, Arakawa O, Sugita H, Deguchi Y, Shida Y, et al. Vibrio alginolyticus, a tetrodotoxin-producing bacterium, in the intestines of the fish Fugu vermicularis vermicularis. Mar Biol. 1987;94:625-30.

OIE. Infection with ranavirus. In: International Office of Epizootics, editor. Manual of diagnostic tests for aquatic animals. Paris: Office International des Epizooties; 2011. p. 14-6.

Paillard C, Le Roux F, Borrego JJ. Bacterial disease in marine bivalves, a review of recent studies: trends and evolution. Aquat Living Resour. 2004;17:477-98.

Panicker G, Myers ML, Bej AK. Rapid detection of Vibrio vulnificus in shellfish and Gulf of Mexico water by real-time PCR. Appl Environ Microbiol. 2004;70: 498-507.

Pedersen K, Skall HF, Lassen-Nielsen AM, Bjerrum L, Olesen NJ. Photobacterium damselae subsp. damselae, an emerging pathogen in Danish rainbow trout, Oncorhynchus mykiss (Walbaum), mariculture. J Fish Dis. 2009;32:465.

Prieta J. Lactococcosis de la trucha arco iris. Med Vet. 1993;10:367-73.

Rasheed V, Plumb JA. Pathogenicity of a non-haemolytic group B Streptococcus sp. in gulf killifish (Fundulus grandis Baird and Girard). Aquaculture. 1984;37: 97-105.

Ravelo C, Magarinos B, López-Romalde S, Toranzo AE, Romalde JL. Molecular fingerprinting of fish-pathogenic Lactococcus garvieae strains by random amplified polymorphic DNA analysis. J Clin Microbiol. 2003;41:751-6.

Reddacliff GL, Hornitzky M, Whittington RJ. Edwardsietla tarda septicaemia in rainbow trout (Oncorhynchus mykiss). Aust Vet J. 1996;73:30.

Romalde JL. Photobacterium damselae subsp. piscicida: an integrated view of a bacterial fish pathogen. Int Microbiol. 2002;5:3-9.

Saulnier D, Avarre JC, Le Moullac G, Ansquer D, Levy P, Vonau V. Rapid and sensitive PCR detection of Vibrio penaeicida, the putative etiological agent of Syndrome 93 in New Caledonia. Dis Aquat Org. 2000;49:109-15.

Soffientino B, Gwaltney T, Nelson DR, Specker JL, Mauel M, Gómez-Chiarri M. Infectious necrotizing enteritis and mortality caused by Vibrio carchariae in summer flounder Paralichthys dentatus during intensive culture. Dis Aquat Org. 1999;38:201-10.

Thampuran N, Surendran PK. Occurrence and distribution of Vibrio vulnificus in tropical fish and shellfish from Cochin (India). Lett Appl Microbiol. 1998;26: $110-2$.

Toranzo AE, Magarinos B, Romalde $\mathrm{J}$. A review of the main bacterial fish diseases in mariculture systems. Aquaculture. 2005;246:37-61.

Xie ZY, Hu CQ, Chen C, Zhang LP, Ren CH. Investigation of seven Vibrio virulence genes among Vibrio alginolyticus and Vibrio parahaemolyticus strains from the coastal mariculture systems in Guangdong, China. Lett Appl Microbiol. 2005; 41:202-7.

Xu X, Zhang L, Weng S, Huang Z, Lu J, Lan D, et al. A zebrafish (Danio rerio) model of infectious spleen and kidney necrosis virus (ISKNV) infection. Virology. 2008;376:1-12.

Zhou S, Hou Z, Li N, Qin Q. Development of a SYBR Green I real-time PCR for quantitative detection of Vibrio alginolyticus in seawater and seafood. J Appl Microbiol. 2007;103:1897-906. 